\title{
A título de preâmbulo
}

Maria Lúcia de Souza Barros Pupo

propósito de iluminar as artes da cena através da perspectiva da educação levou à constituição do conjunto de textos apresentado nas próximas páginas.

Uma vez que o pensamento sobre as contribuições do teatro e da dança para o crescimento do homem já se configura na Grécia antiga, é inegável que as concepções atuais sobre esse campo são tributárias de um longo trajeto histórico. Assim, as inquietações que nos movem hoje em relação ao tema são inseparáveis do percurso trilhado, tanto pelas artes cênicas, quanto pelas ciências da educação, até a contemporaneidade. Algumas dessas interrogaçôes, coladas aos complexos desafios de nosso tempo, fazem-se presentes a seguir.

Reunimos aqui traços de investigações que vêm contribuindo para o avanço do conhecimento sobre as relaçôes entre as artes cênicas e a educação no nosso âmbito acadêmico. Em alguns casos são apresentadas sínteses de pesquisa; em outros, somos confrontados a recortes e a desdobramentos de investigaçôes recentemente concluídas na área.

Os autores nos dão notícias de pesquisas de natureza diversa. Algumas se organizam predominantemente em torno de eixos históricos, enquanto outras apresentam caráter institucional. Muitas delas se aventuram numa seara tão delicada quanto fascinante, mais e mais explorada nas últimas décadas: a da pesquisa em torno de processos de criação artística. É certamente no âmago desta última que se coloca de modo mais agudo a necessidade de experimentação em termos da busca de soluções para os problemas do registro da pesquisa e do necessário rigor nas formulações. Respostas originais nesse sentido vêm sendo dadas por autores que escolheram a pesquisa-ação como modalidade de trabalho. Processos de criação em artes cênicas envolvendo dispositivos dialógicos, através dos quais se dá a co-participação do pesquisador e das pessoas implicadas no problema investigado, constituem, sem dúvida, campos férteis dentro dos quais se pode superar pretensas dicotomias, tais como teoria versus prática.

No que diz respeito às esferas de atuação nas quais tais processos ocorrem, a diversidade é também a tônica: pessoas de várias idades $\mathrm{e}$ condição social estão envolvidas. Além da instituição escolar, podemos observar processos cênicos sendo desenvolvidos e estudados em centros culturais de diferentes portes, no âmbito de movimentos sociais e do desempenho de ONGs em prisões e no campo da saúde mental, entre outros.

A leitura dos textos revela como concepções de autores europeus e americanos, referências

Maria Lúcia de Souza Barros Pupo é professora titular do Departamento de Artes Cênicas da ECA-USP. 
importantes no campo, são continuamente reelaboradas entre nós, dando origem a interessantes experimentações em contextos específicos de nosso país, marcados por desigualdades sociais gritantes, mas também por manifestaçōes de uma cultura rica e multifacetada.

Isabel de Azevedo Marques examina criticamente repercussóes do trabalho de uma das personalidades mais marcantes da dança do último século, Rudolf Laban, no quadro artístico e educacional brasileiro. Os demais artigos remetem a diferentes aspectos de uma pedagogia do teatro. A legislação brasileira do ensino do teatro no Brasil e as orientações atuais da UNESCO a respeito são tratados por Arão Paranaguá de Santana.

A problemática da fruição teatral é objeto de três textos. Ingrid Dormien Koudela analisa a elaboração de significados pessoais realizada por crianças a partir de Sonho de uma noite de verão, situando a relação entre o fazer e o apreciar à luz das novas propostas para o ensino do teatro. Flávio Desgranges mostra-nos como os desafios da contemporaneidade exigem que uma atitude de caráter mais autoral seja suscitada no espectador. Referência importante nessa última pesquisa, as posições de Roger Deldime são aqui exemplificadas através de uma prática de formação vinculando a leitura do espetáculo e a realização de cenas por parte de crianças e jovens.

Dois trabalhos abordam mais particularmente as implicações de processos teatrais desenvolvidos juntos a grupos de jovens ameaçados pela exclusão social. Paulo Bareicha analisa as dificuldades encontradas na coordenação de situações dramáticas formuladas por adolescen- tes inseridos em programa de "liberdade assistida”. Rogério Moura discute as condições da adesão de jovens da periferia paulistana a programas de educação e cultura caracterizados por visível fragilidade.

Investigações voltadas mais particularmente para o sistema de jogos teatrais perpassam vários artigos. Robson Camargo traz à tona a influência da educadora americana Neva Boyd na proposta de theater games formulada por $\mathrm{Vi}$ ola Spolin. A superação da dicotomia entre processos de criação e apresentação de resultados, possibilitada pela prática dos jogos teatrais, é apontada por Joaquim Gama. A experimentação lúdica enquanto fio condutor de uma encenação cuja dramaturgia é elaborada pelo conjunto dos participantes, constitui a contribuição de Marcos Bulhões Martins.

Beatriz Ângela Cabral sistematiza noções acerca da avaliação no ensino de teatro e do "drama", com base em análise histórica da bibliografia específica de origem anglo-saxônica, e Marina Marcondes Machado argumenta em favor do "diário de bordo", instrumento de registro coerente com a vertente fenomenológica de pesquisa em artes cênicas.

Os artigos que se seguem têm em comum o fato de colocarem em relevo possibilidades de fazer e fruir teatro e dança, que, sem dúvida, traduzem rupturas com modelos dominantes de consumo de espetáculos. Eles se referem a práticas artísticas tecidas a ações educativas, sociais, e em última análise, sempre políticas. Mediante a experiência dessas práticas, amplia-se a consciência de quem vive o processo: um modo peculiar de conhecer o mundo passa a ser apreendido. 